official duties, yet in continuous touch with the whole meteorological world, wasting no time over controversy, keen to appreciate the scientific laws and scrupulous impartially to place everything that complied therewith at the service of the whole scientific world.

Fully occupied in the enjoyment of his work, he was too busy for journeys that would separate him from it. Since 1898 he has not often been seen outside Vienna or his summer resort. He leaves a widow, a son, and two daughters to mourn his loss, which calls forth the assured sympathy of colleagues and friends in all parts of the world.

Hann received many distinctions. $\mathrm{He}$ was "Hofrat" in I89r, and subsequently was ennobled with the prefix "von"; but he made little display of the distinction. He had also the Ehrenzeichen für Kunst und Wissenschaft, and was a Knight of the Prussian Order "Pour le Mérite," a member of the Academy of Vienna, and honorary or foreign member of foreign academies and societies in all parts of the world. He was the recipient of the Buys Ballot medal, the Symons medal, and many other recognitions of his preeminent services.

Napier SHaw.

\section{BENJAMIN HARRISON.}

The late Benjamin: Harrison was born on December I4, I837, at Ightham, Kent, where his family had resided for several generations. Educated locally, he had the good fortune to be trained by two schoolmasters interested in science and archæology, and thus the natural trend of his mind was greatly stimulated. On leaving school at the age of fifteen he entered his father's shop, and after his father's death carried on the business of grocer until a few years ago. He passed peacefully away on October I after a few days' illness in the house in which he was born. He was married twice, his first wife dying in 1877 , and his second wife (for many years an invalid) surviving him only a week. He leaves one son and two daughters.
In early life Harrison was a keen botanist and an enthusiastic collector of fossils and flint implements, and he soon got in touch with such wellknown workers as the late Lord Avebury, F. C. J. Spurrell, and Roach Smith. In 1870 he met the late Sir Joseph Prestwich, who, perceiving the importance of his discoveries, encouraged him in many ways. As a result of Harrison's field work, Prestwich, in r889, published his well-known paper on the Palæoliths of Ightham (Quart. Journ. Geol. Soc., vol. 45, pp. 270-294), followed in $189 \mathrm{I}$ by the Darenth paper (op. cit., vol. 47 , pp. $120-160$ ), and in 1892 by the paper on the plateau implements (Journ. Anthrop. Inst., vol. 2 I, pp. 246-262), Prestwich claiming for these rudely chipped flints a much greater antiquity than the Palæoliths. This was the beginning of the great "Eolithic" controversy which has not yet received its final solution, and it would appear as though there will always be two opinions respecting "Eoliths." Henceforward Harrison's spare time was spent in accumulating evidence in support of the "Eoliths" and in elucidating other prehistoric problems, whilst his house became a Mecca for all students.

Harrison's name will always be associated with "Eoliths," but it was his evidence that enabled Prestwich to establish the "hill group" of Palæoliths whilst the excavations carried on by Harrison at the rock shelters at Oldbury yielded many late Palæoliths which are now regarded as St. Acheul II. Harrison published but little, yet no one was more willing to assist others with his knowledge. An extremely well-read man, his ready wit, kindness of heart, and cheerful disposition endeared him to a large circle of friends, who now mourn the loss of "old Ben." In 1895 he was awarded the Lyell fund by the Geological Society, and in later life he was the recipient of a Civil List pension. Harrison was one of those humble workers for science who, in the face of great difficulties, rise superior to their surroundings by strength of character and industry, and leave an imperishable name behind.

\title{
Notes.
}

AT a meeting of the Optical Society held on Thursday, October $\mathrm{I}_{3}$, the resolution passed early in $\mathrm{I}_{9} \mathrm{I}_{5}$ suspending certain members, subjects of countries then at war with Great Britain, was revoked.

THE Thomas Hawksley lecture of the Institution of Mechanical Engineers for the present year is to be delivered at the institution on Friday, November 4, at 6 o'clock, by Dr. H. S. Hele-Shaw, who will take as his subjec "Power Transmission by Oil."

At the opening of the annual meeting of the Societé de Chimie industrielle on October Io the Dumas medal of the society and an illuminated address were presented by M. Dior, Minister of Commerce, to Sir William J. Pope.

$$
\text { NO. } 27 \text { I2, VOL. I08] }
$$

"EARly Relations of Egypt, Babylonia, and Syria" is the subject of a lecture to be delivered by $\mathrm{Mr}$. Percy E. Newberry on Thursday, October 27, at 8.30 p.m., at the rooms of the Royal Society, Burlington House. This lecture is the first of a series on Egypt to be arranged by the Egypt Exploration Society. Tickets and further details can be obtained from the Secretary, I3 Tavistock Square, W.C.I.

THE programme for the session $192 \mathrm{I}-22$ of the Institute of Metals contains, in addition to announcements of general meetings of the institute, the first list of meetings of the newly-formed. London Local Section. There are now in existence local sections in Birmingham, Sheffield, Glasgow, and London, and 